\title{
BUSINESS TOURISM DESTINATION \\ COMPETITIVENESS: A CASE OF VOJVODINA \\ PROVINCE (SERBIA)
}

\author{
VANJA DRAGIĆEVIĆ ${ }^{1}$, DOBRICA JOVIČIĆ ${ }^{2}$ \\ IVANA BLEŠIĆ ${ }^{3}$, UGLJEŠA STANKOV \\ DESIMIR BOŠKOVIĆ
}

\section{ARTICLE INFO}

JEL classification: L83, O20, C12,

Keywords:

- Destination

- Competitiveness

- Business tourism

- Vojvodina
ABSTRACT

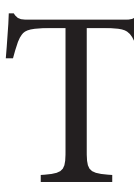

he main purpose of this article is to create model of business tourism destination competitiveness and test it on the example of Vojvodina Province, tourist cluster in Serbia, where business tourism is defined as one of key tourist products. The paper aims to examine in which areas Vojvodina Province is more competitive as a business tourism destination and where it is less competitive compared to "competitive set" of three chosen destinations. Also, this paper aims to test relationships between destination competitiveness determinants in order to determine the weakest point of Vojvodina Province business tourism competitiveness, and specifically the position of destination management. The study results indicate that two determinants: destination management and destination policy, planning and development are the weakest points of Vojvodina Province competitiveness, while highest ratings are assigned to core resources and attractors determinant. The results will be most valuable in assisting destination management organizations, tourism policy creators and tourism practitioners to better understand identified destination advantages and problems in business tourism and general tourism development in Vojvodina Province, and to formulate strategies to effectively manage destination disadvantages.
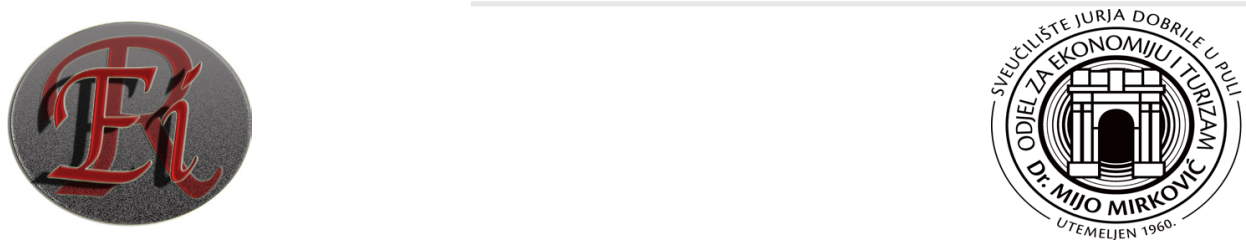

\footnotetext{
${ }^{1}$ University of Novi Sad, Faculty of Sciences, Department of Geography, Tourism and Hotel Management, 0038121450602 , vanja.dragicevic@dgt.uns.ac.rs, Trg Dositeja Obradovića 3, 21000 Novi Sad, Serbia

${ }^{2}$ University of Belgrade, Faculty of Geography, dobricaj@eunet.rs, Studentski trg 3/III, 11.000 Belgrade, Serbia

${ }^{3}$ University of Novi Sad, Faculty of Sciences, Department of Geography, Tourism and Hotel Management, 0038121450602 , ivana.blesic@gmail.com, Trg Dositeja Obradovića 3, 21000 Novi Sad, Serbia

${ }^{4}$ University of Novi Sad, Faculty of Sciences, Department of Geography, Tourism and Hotel Management, 0038121450602 ,
stankovugljesa@yahoo.com, Trg Dositeja Obradovića 3, 21000 Novi Sad, Serbia
}

${ }^{5}$ Institute of Agriculture and Tourism, desimir@iptpo.hr, C. Huguesa 8, 52440 Poreč, Croatia 


\section{INTRODUCTION}

The number of tourism destinations worldwide is constantly growing. As destinations strive for bigger market shares, there is great competition on the international tourism market. Competitiveness is increasingly being seen as a critical influence on the performance of tourism destinations in competitive world markets (Enright, Newton, 2005).

Crouch and Ritchie (2000, p.6) stated that tourism destination competitiveness "has tremendous ramifications for the tourism industry, and is therefore of considerable interest to practitioners and policy makers." Moreover, Enright and Newton (2005, p.340) stated that "a destination is competitive if it can attract and satisfy potential tourists, and this competitiveness is determined by both tourism specific factors and a much wider range of factors that influence the tourism service providers."

In tourism industry, competition among territorial areas is usually not centred on the single aspects of the tourist product (environmental resources, transportation, tourism services, hospitality, etc.), but on the tourist destination as an integrated set of facilities for the tourist (Buhalis, 2000; Ritchie \& Crouch, 2000). In an ever more saturated market, the fundamental task of destination management is to understand how tourism destination competitiveness can be enhanced and sustained. There is thus a strong need to identify and explore competitive (dis)advantages and to analyze the actual competitive position (Gomezelj, Mihaljič, 2008). Identifying competitors and determining the destination advantages and disadvantages relative to competitors is an integral part of successful marketing management of tourist destinations.

During the past couple of decades, the research body on tourism destination competitiveness has grown. General models of destination competitiveness have been developed with an extensive list of determinants and attributes. But although the list is extensive, they are unlikely all to be of equal importance or influence in determining the competitiveness of destinations. A destination should therefore be wise to focus attention on those attributes that are likely to have the greatest beneficial impact to particular segments of the tourism market (Crouch, 2010).

Business travellers represent growing segment of the international tourism market and business tourism is considered as one of most desirable forms of tourism development at destinations worldwide. According to WTO (2007), business tourism is high quality and high yield, can be positioned as a key part of an economic development strategy and the sector is resilient to the types of events and economic downturns that affect leisure tourism. Therefore, the number of destinations that recognized benefits of business tourism development is constantly increasing, thus, the competition is more intensive now than it used to be.

Tourism industry in Serbia and countries in the region (Hungary, Croatia, Slovenia and Romania) show great interest in business tourism development. These countries continuously put new venues and facilities on the market and compete in attracting international business events. The Vojvodina Province, as one of four tourist clusters in Serbia, represents an attractive location for holding business events and has a long tradition of organizing fairs and congresses. Different strategic and planning documents recognized tourism as an activity that could stimulate whole economy development through jobs creation, investments in 
(tourism) infrastructure and tourism complementary activities. Moreover, business tourism is considered as one of quick-win tourist products in Vojvodina, as well as in whole Serbia, which could improve destination image and provide competitive position in short time on the international tourism market. However, there are no studies about tourism, and specifically business tourism competitiveness of Vojvodina Province.

The main purpose of this article is to create and test model of business tourism destination competitiveness, which will include general tourism-related factors and specific business tourism factors that affect destination competitiveness. Different hypotheses are created to determine in which areas Vojvodina Province is more competitive as a business tourism destination and where it is less competitive. It is aim to deal with the following research questions:

1. What is the weakest point in Vojvodina Province business tourism competitiveness?

2. What is the position of tourism management?

The article is divided into six sections. The paper starts with the theory on tourism destination competitiveness and business tourism. The methodology used is presented in section four, which is followed by research results in section five. Section six includes conclusions, limitations of the research, and future research directions.

\section{THEORY ON TOURISM DESTINATION COMPETI- TIVENESS}

As a concept in business, management and international trade, competitiveness has received widespread interest and attention (Ritchie and Crouch, 2003). Attempts to conceptualize and analyze competitiveness have come from a variety of different academic disciplines, including economics, management, politics and culture, each with its own perspective on the subject.

Scott and Lodge (1985, p.3) viewed national competitiveness as "a country's ability to create, produce, distribute, and service products in international trade while earning rising returns on its resources". They also noted that this ability "is more and more a matter of strategies, and less and less a product of natural endowments". The Organization for Economic Cooperation \& Development (OECD) (The World Competitiveness Report, 1994) defines competitiveness as "the ability of a country or company to, proportionally, generates more wealth than its competitors in world markets". Competitiveness is viewed as combining both assets and processes where assets are inherited (e.g., natural resources) or created (e.g., infrastructure) and processes transform assets into economic results (e.g., manufacturing).

Ritchie and Crouch (2000) viewed a destination's competitiveness as a country's ability to create added value and thus increase the national wealth by managing assets and processes, attractiveness, aggressiveness and proximity, and there by integrating these relationships within an economic and social model that takes into account a destination's natural capital and its preservation for future generations (Ritchie and Crouch, 2003).

Hong (2008, p.6) defines tourism competitiveness as the ability of a destination to create, integrate and deliver tourism experiences, including value-added goods and services considered 
to be important by tourists. These experiences sustain the resources of a destination, and help it maintain a good market position relative to other destinations.

Competitiveness has been associated in the tourism literature as a crucial factor for the success of tourist destinations (Kozak and Rimmington, 1999; Crouch and Ritchie, 1999; Mihalic, 2000; Buhalis, 2000; Dwyer and Kim, 2003; Gooroochurn and Sugiyarto, 2005; Enright and Newton, 2004; Mangion et al., 2005; Mazanec et al., 2007; Chen, 2008). Tourism studies, in general, seem to imply that by being competitive a tourist destination could expand its tourism industry and hence the quality of life of the populace (Crouch and Ritchie, 1999; Dwyer and Kim, 2003; Sahli, 2006; Kim et al., 2006).

A number of authors have provided some inputs into the understanding and practical research of competitiveness in tourism destinations (De Keyser and Vanhove, 1994; Evans, Fox and Johnson, 1995; Faulkner et al., 1999; Hassan, 2000; Ritchie and Crouch, 1993; Crouch and Ritchie, 1999; Crouch and Ritchie, 2000; Ritchie and Crouch, 2003; Dwyer et al., 2000, 2002; Enright and Newton, 2004, 2005; Bonn et al., 2005; Cracolici and Nijkamp, 2008; Crouch, 2010; Miller et al., 2008; Dragićević et al., 2009). But, there seems to be no generally accepted definition of competitiveness and the means to measure it (Croes 2005; Papatheodorou and Song 2005, Gomezelj and Mihalič, 2008).

In order to measure competitiveness of the destination, different models were created. These models differ by the elements (indicators) which are used to measure the competitiveness.

Well known Porter's (1990) “diamond of national competitiveness" includes aspects of both the multidimensional strand of economics together with an emphasis on the management and strategy field, focuses not on the competition between national economies but rather on the competition between, and competitiveness of, specific industries in different locations. This four-part framework, which was based on research undertaken in eight advanced and two newly industrialized countries, postulates that success in international competition in a given industry depends on the relative strength of an economy in a set of business-related features or "drivers" of competitiveness, namely, factor conditions, demand conditions, related and supporting industries, and firm strategy, structure, and rivalry specifically related to the industry (Enright and Newton, 2005). This approach found its application in measuring tourism destination competitiveness. De Holan and Phillips (1997, p.781) explicitly recommend the inclusion of Porter's framework, particularly when examining tourism in developing countries.

The authors De Keyser and Vanhove in their competitiveness model (1994) argue that the analysis of a competitive position should take five groups of competitiveness factors into account: tourism policy, macroeconomic, supply, transport and demand factors. This model was used by Sirše and Mihalič (1999) in measuring Slovenian tourism competitiveness.

Mihalič (2000) studied destination competitiveness from environmental perspective. The environmental component was also considered in Hassan's model (2000). The model defined a destination's commitment to the environment as one of the four determinants of tourism competitiveness; and included also comparative advantage, industry structure and demand factors (Gomezelj and Mihalič, 2008).

Dwyer et al. (2003) tested Integrated model of destination competitiveness on the cases of Korea and Australia and in 2004 its methodology was applied to evaluate the tourism 
competitiveness of Slovenia (Gomezelj and Mihalič, 2008). The Integrated model defines six main determinants of competitiveness: inherited resources, created resources, supporting factors and resources, destination management, situational conditions and demand conditions. Inherited, created and supporting resources encompass the various characteristics of a destination that make it attractive to visit. Destination management determinant embraces the activities of destination management organisations, destination marketing management, destination policy, planning and development, human resources development and environmental management. This determinant (should) enhance the attractiveness of the inherited and created resources and improve the supporting factors quality. The factors of situational conditions are destination's location, micro and macro environment, security and safety, price competitiveness. These factors can moderate, modify or even mitigate a destination's competitiveness. Demand conditions include awareness, perception and preferences of tourism demand (Kim and Dwyer, 2003).

Well-known tourism competitiveness researchers Ritchie and Crouch (2003) presented the most recently improved version of their competitiveness model: a Conceptual Model of Destination Competitiveness, which is among the best known of recent attempts to conceptualize an approach that includes elements of tourism competitiveness and industry competitiveness and has undergone a number of iterations since its earliest public presentation (Ritchie and Crouch, 1993). Some of the variables identified by Crouch and Ritchie (1999) have been included in the above mentioned Integrated model of destination competitiveness.

Ritchie and Crouch (2003) model includes five key determinants: destination policy, planning and development, qualifying and amplifying determinants, destination management, core resources and attractors, and supporting factors and resources. It also points out the importance of the global macro environment and the competitive microenvironment surrounding the destination. Core resources and attractors are "the fundamental reasons that prospective visitors choose one destination over another" (Crouch and Ritchie, 1999, p.146). This determinant includes physiography (landscape and climate), culture and history, market ties (linkages with the residents of tourism originating regions), activities, special events, and the tourism superstructure (primarily accommodation facilities, food services, transportation facilities, and major attractions). Supporting factors and resources consist of accessibility, entrepreneurship, communications infrastructure, local transportation infrastructure, and other inputs provided by public services, institutions (financial, education, and research), and the principal factors of production. Destination management embraces destination promotion, service levels, information systems, the organization of destination management activities, and sustainable resource stewardship. Qualifying and amplifying determinants include safety, location, interdependencies within and between destinations, and cost (in a broad sense includes interdestination travel, local living costs, and exchange rate effects). Finally, destination policy, planning, and development determinant consists of system definition, philosophy, vision, audit, positioning, development, competitive/collaborative analysis, monitoring, and evaluation.

In this study, the main determinants of Ritchie and Crouch (2003) destination competitiveness model have been kept. 


\section{BUSINESS TOURISM DESTINATION}

In business tourism, the competition among destination is more intensive now than it used to be, as countries worldwide continuously put various meeting venues and facilities on the market. Therefore, in this section of the article, it is necessary to define business tourism as a type of tourism, and, moreover, variables or factors that affect competitiveness of a business tourism destination should be discussed in order to explain development of a model used in this study for measuring business tourism destination competitiveness.

According to WTO (2007, p.18), business tourism is seen as "a travel to attend an activity or event associated with business interest". Main components of business tourism are: meetings, incentives, conventions and exhibitions. Similar to WTO (2007), Davidson and Cope (2003) grouped four sectors: meetings, incentive trips, exhibitions and corporate hospitality, as business tourism. Davidson (1994) states that business tourism is concerned with people travelling for purposes related to their work. According to Swarbrook and Horner (2001), business tourism brings great benefits to destinations and has a number of advantages over leisure tourism. Thus, every year, destinations worldwide compete in attracting business events such as conventions, exhibitions, incentive travels.

According to Crouch and Weber (2002), the service provided in a destination and its facilities are critical to the success of the meeting destination. A business tourism destination has to offer a suitable venue for the meeting, sufficient accommodation (if a venue is nonresidential), attractions, good accessibility to the generating markets and efficient transport system within the destination (Swarbrooke and Horner, 2001).

Numerous studies have investigated specific destination variables that influence the selection of a destination for holding business events and its competitiveness (Ching-Fu, 2006; Crouch and Ritchie, 1998; DiPietro et al., 2008; Oppermann, 1996; Baloglu and Love, 2001; Crouch and Louviere, 2004; Chacko and Fenich, 2000; Oppermann and Chon, 1997; Yoo and Chon; 2008, Zhang et al., 2007; Kim and Kim, 2003; Qu et al., 2000).

Crouch and Ritchie (1998) grouped 36 destination attributes, that govern a choice of meeting destination, into a set of eight primary categories: accessibility (cost, time, frequency, convenience, and barrier attributes), local support (local chapter, convention and visitors' bureau/convention center, and subsidies attributes), extra conference opportunity (such as entertainment, shopping, sightseeing, recreation, and professional opportunities), accommodation facilities (capacity, cost, service, security and availability), meeting facilities (capacity, layout, cost, ambiance, security, availability and experience attributes), information (reputation and marketing attributes), site environment (including climate, setting, and infrastructure attributes) and other criteria (such as risks, profitability, association promotion and novelty attributes). In a study of the competitiveness of Hong Kong as an international conference destination in South-east Asia, Qu et al. (2000) concluded that accommodation, convention facilities, accessibility, safety and infrastructure system were perceived as important site selection criteria. In the analysis of Seoul as an international convention destination, Kim and Kim (2003) state that meeting room facilities, service quality, restaurants, transportation and destination attractiveness are the major attributes for choosing one destination for holding business events. According to Crouch and Weber (2002), although 
the literature has highlighted the importance of the available meeting and accommodation facilities, it is clear that a number of additional destination attributes (such as accessibility of the congress site to the majority of attendees, attractive pre and post congress recreational or vacationing opportunities, appealing destination image) play critical roles in destination selection process. Chacko and Fenich (2000, p. 218) state that "the promotional appeal of a site is a vital contributor to overall convention destination attractiveness". In study on convention site selection in Australia, Crouch and Louviere (2004) concluded that convention and accommodation facilities are critical, but one destination must offer additional attributes to succeed in an ever more competitive environment. "Destinations need to create unique combinations of attributes to develop strong competitive positions" (Crouch and Louviere, 2004, p.128), using knowledge of the factors that meeting planners and buyers value most in their site choice decisions.

\section{METHODOLOGY}

The model on measuring business tourism destination competitiveness was created based on the above mentioned Ritchie and Crouch (2003) Conceptual Model of Destination Competitiveness and a set of factors that affect destination (site) selection for holding business events. The main determinants of Ritchie and Crouch (2003) model are kept, with general tourism destination attributes which were adapted to Vojvodina Province tourism characteristics. Specific business tourism factors that affect destination competitiveness were added after literature review presented in the section 3 of the article. The model resulted in 54 destination attributes which were grouped into each of five determinants of Ritchie and Crouch (2003) model: core resources and attractors (including 17 attributes), supporting factors and resources (including 5 attributes), qualifying and amplifying determinants (including 10 attributes), destination management (12 attributes) and destination policy, planning and development determinant (10 attributes).

As given destination is competitive or uncompetitive against relevant competing destinations, it is important to establish which destinations comprise the competitive set (Kozak and Rimmington, 1999). In literature, the competitive set is usually comprised of three to five destinations (Enright and Newton, 2004, 2005; Gomezelj and Mihalič, 2008; Crouch, 2010). Therefore, in this study the respondents were asked to indicate major three competitor destinations of Vojvodina Province. The majority of respondents (52.5\%) established a competitive set comprising of Hungary, Croatia and Slovenia. According to $14.4 \%$ of respondents, the major competitors of Vojvodina Province business tourism are Hungary, Croatia and Belgrade tourist cluster (Serbia).

In the second stage, the respondents were asked to evaluate Vojvodina Province competitive performance on a five-point Likert scale, ranging from 1 (well below the same level in competitive destinations) to 5 (well above the same level in competitive destinations), for each of the 54 attributes compared to its competitor destinations, in order to indicate the weakest points in Vojvodina Province business tourism.

The survey was conducted in 2010 . The survey questionnaire was distributed by e-mail to travel industry practitioners and tourism stakeholders on the supply side (tourism industry, 
government, tourism school academics and postgraduate students on tourism management courses). "It is a common practice in research in the generic management field, including competitiveness research, for the survey population to be managers and other industry practitioners, as this is the population seen to be the most knowledgeable about management and competitiveness" (Enright and Newton, 2005, p.343). Although tourists are able to evaluate a destination's attractiveness, they are less able to evaluate factors such as destination management or destination policy. Formica (2002) discusses that both experts' and tourists' evaluations of destination competitiveness could have the highest degree of accuracy. However, the literature supports targeting industry practitioners in measuring destination competitiveness (Faulkner et al., 1999; Gomezelj and Mihalič, 2008; Enright and Newton, 2004, 2005; Crouch, 2010). From the 358 questionnaires sent out, 118 were completed in a correct way. The SPSS standard package version 17 for personal computers was used for data processing.

\section{STUDY RESULTS}

\section{A. Sample characteristics}

According to gender, $60.2 \%$ respondents were female and $39.8 \%$ male. The majority of respondents were young, up to 35 years (67.8\%), followed by $20.3 \%$ in the age group between 36 and 50 years, while the respondents with more than 50 years represented $11.9 \%$ of the sample. All of respondents had completed university levels of education. Of 118 respondents, $13.6 \%$ were government officials, $5.9 \%$ were employers in local tourist organisations, $4.2 \%$ employers in congress bureau and congress centres. The largest response rate was from tourism academics (39\% of the sample) and postgraduate students on tourism management courses (22.9\%). Also, the sample included tourist agency managers (5.1\% of the respondents) and hospitality sector managers $(4.2 \%)$, while $5.1 \%$ were represented by others. The sample consisted of $60.2 \%$ of respondents who had been linked with the tourism industry for up to 5 years, $22.9 \%$ of them from 6 to 10 years and $16.9 \%$ for more than 10 years.

\section{B. Competitiveness by destination determinants}

As above mentioned, individual destination attributes of Vojvodina Province are grouped into the five main determinants of Ritchie and Crouch (2003) Conceptual Model of Destination Competitiveness. Thus, the competitiveness of individual destination attributes is analysed by each competitiveness determinant, in order to evaluate the weakest, as well as the strongest attributes of Vojvodina Province tourism.

Core resources and attractors. As figure 1 show, the highest rating was assigned to the following destination attributes: multicultural ambience, gastronomy offer, entertainment, festival and events and the attractiveness of cultural heritage. This was expected as Vojvodina Province is one of the most heterogeneous regions in Europe considering ethnic structure. Different ethnic groups living in the region have preserved its tradition, customs, and gastronomy and presented it on tourist market mostly in the form of different festivals. The smallest standard deviation for multicultural ambience $(\sigma=0.72)$ and gastronomy offer 
$(\sigma=0.73)$ indicates quite a high level of agreement between the respondents. Also, among all 54 attributes, the respondents assigned the highest rating to these two attributes, which therefore represent the primary attractors of Vojvodina Province. In the context of business tourism development, multicultural ambience and rich gastronomy offer contribute to destination attractiveness, which is important (sometimes prevailing) element in the bid process, when choosing destination for a congress or a conference. Also, these attributes could be important segments of incentive travel arrangements. Presence of five and four star hotels, as well as of professional congress organizers (PCO), signalling on roads related to tourist attractions, quality of hotel services, shopping opportunities and congress centres are all rated relatively low.

Supporting factors and resources. Only one out of the five supporting factors, hospitality of local residents, is rated as being more competitive in comparison to the chosen set of three competitive destinations. Accessibility of destination is not seen as advantage or disadvantage of Vojvodina Province tourism industry as it is "at the same level" $(\mathrm{M}=3)$ as at competitors. Although strategic documents on tourism development highlight valuable economic and social contribution made to society by tourism industry, political will and incentives for tourism development in Vojvodina Province are rated low $(\mathrm{M}=2.36)$. Presence of foreign/international companies on business tourism destination is important competitiveness indicator in terms of holding corporate business events and organizing incentive trips. This attribute, as well as quality of local transportation services are rated as being less competitive in comparison to the chosen set of competitive destinations.

Qualifying and amplifying determinants are "factors of competitiveness that moderate, modify, mitigate and filter, or magnify, strengthen, enhance and augment the impact of all other determinants" (Ritchie and Crouch, 2003, p.233). Compared to its competitive destinations, Vojvodina Province is regarded as being more competitive than its competitors in only four out of 10 attributes: location, transport and hotel services costs and destination safety. As business events are usually attend by intellectual and business elite, as well as representatives of local/national authorities, safety issue is important indicator of business tourism destination competitiveness. According to respondents, Vojvodina Province is perceived as a safe destination. However, low ratings given for overall destination image, political stability, value for money, destination cleanliness, economic stability and online booking of accommodation should alarm tourism stakeholders as well as destination management organization and government. 


\section{FIGURE 1}

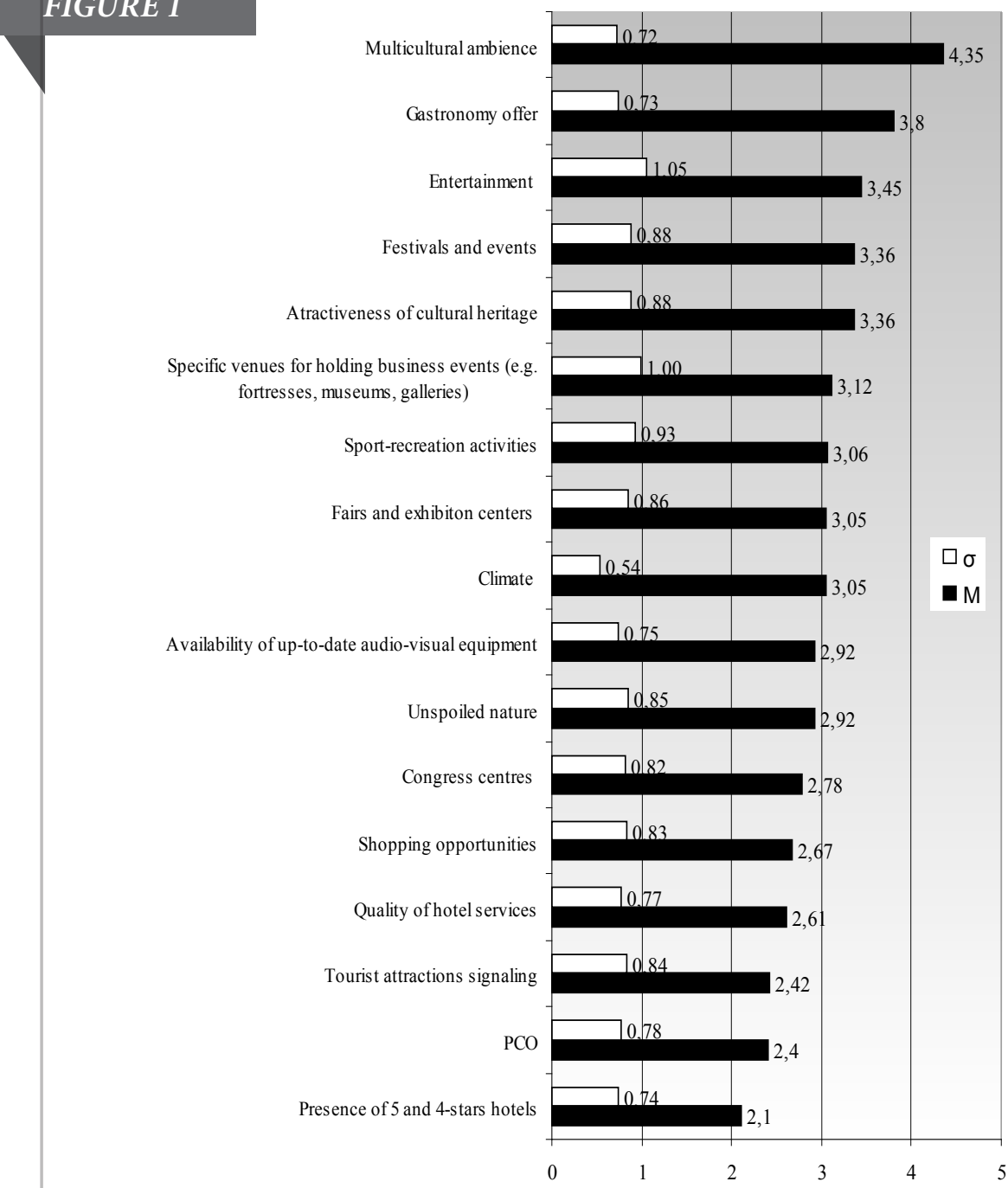

SOURCE: Author 
MEAN VALUES (M) AND STANDARD DEVIATIONS ( $\Sigma$ ) FOR INDIVIDUAL ATTRIBUTES OF SUPPORTING FACTORS AND RESOURCES DETERMINANT

\section{FIGURE 2}

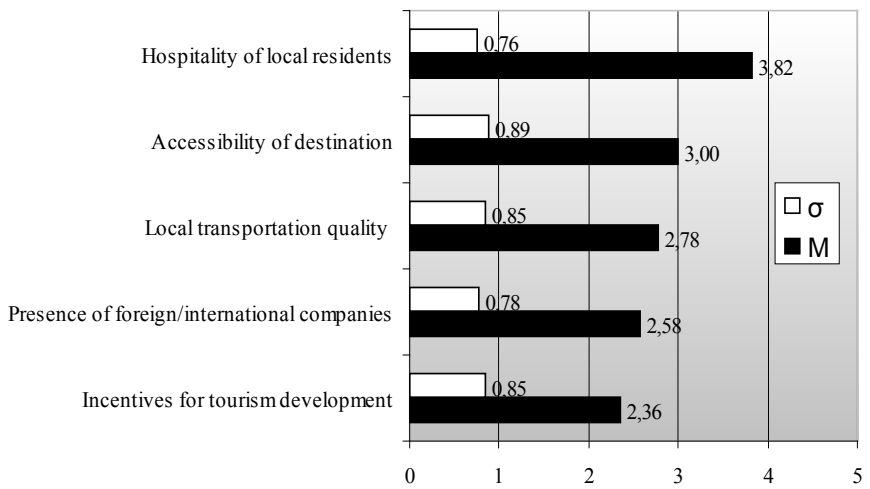

SOURCE: Author

MEAN VALUES (M) AND STANDARD DEVIATIONS ( $\Sigma$ ) FOR INDIVIDUAL ATTRIBUTES OF QUALIFYING AND AMPLIFYING DETERMINANTS

\section{FIGURE 3}

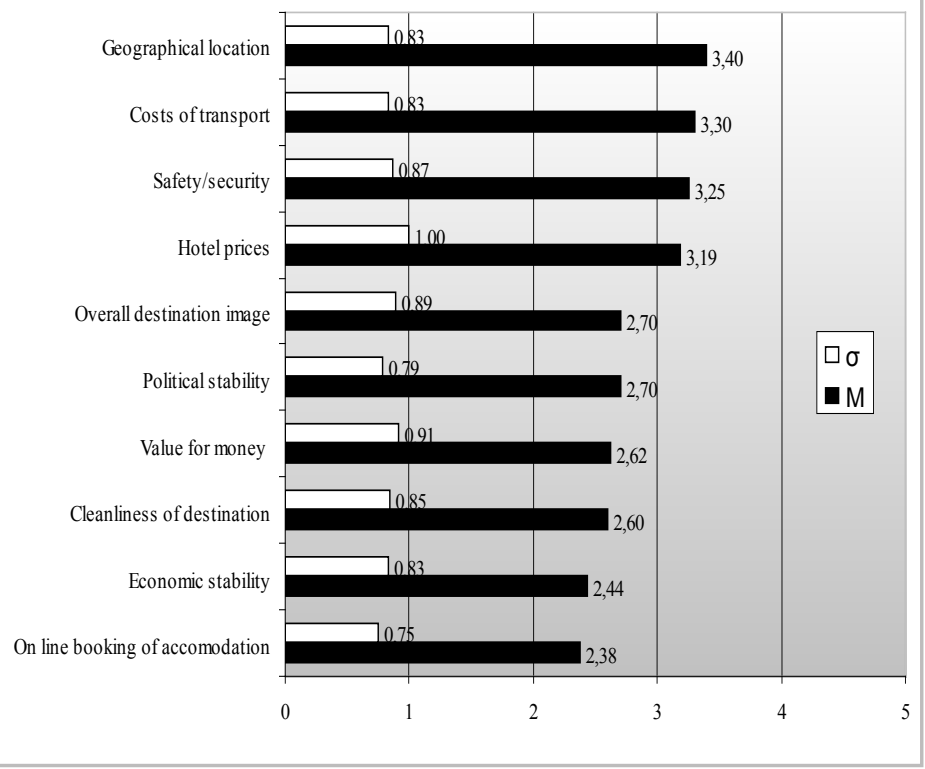


Destination management. Considering ratings given for destination management factors, Vojvodina Province is less competitive in all factors compared to competitive set of destinations (Fig. 4). Also, low standard deviation for almost all factors indicates a high level of agreement among respondents in ratings of this determinant.

\section{MEAN VALUES (M) AND STANDARD DEVIATIONS $(\Sigma)$ FOR INDIVIDUAL ATTRIBUTES OF DESTINATION MANAGEMENT}

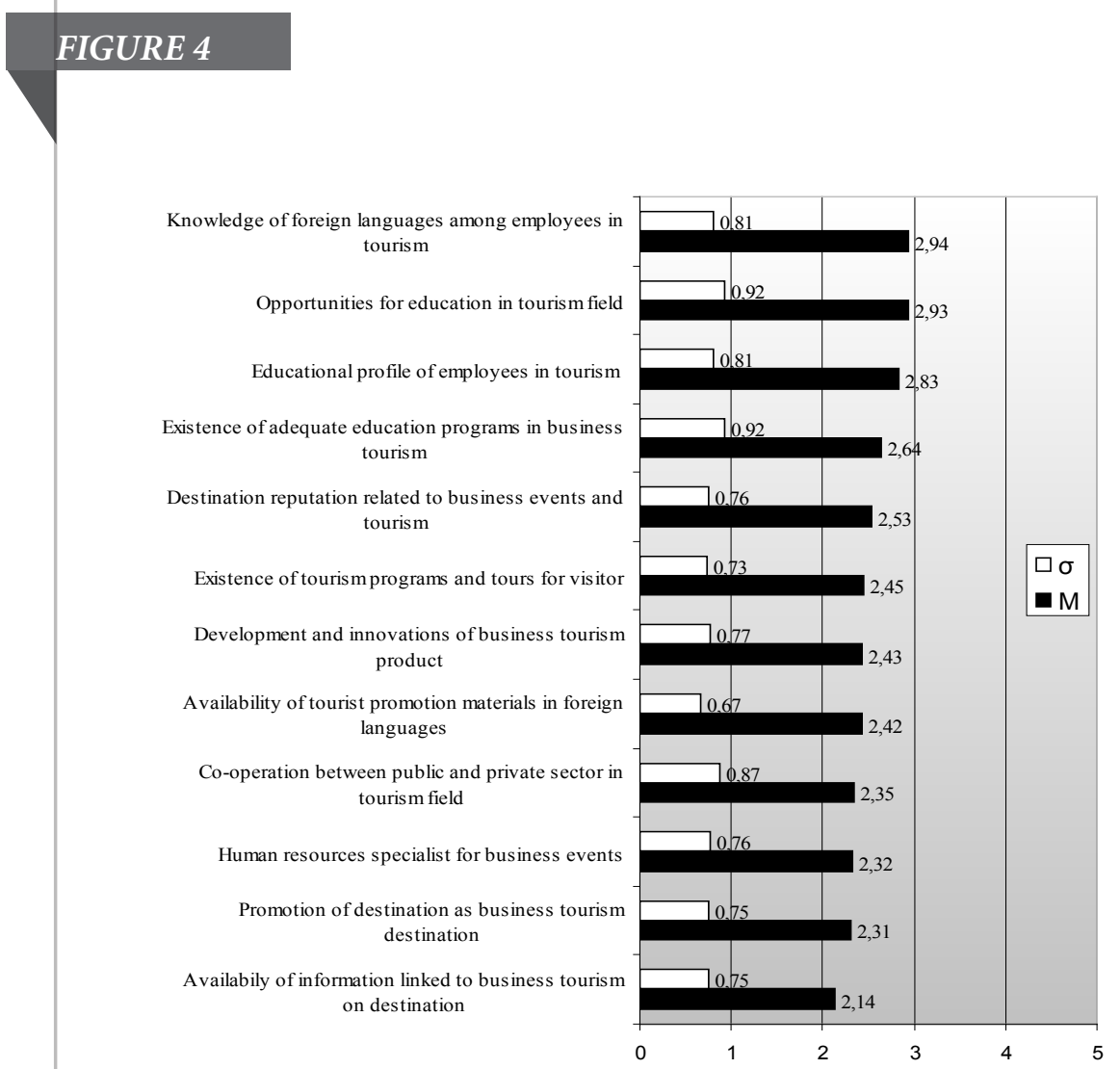

SOURCE: Author

Destination policy, planning and development determinant is closely connected to destination management determinant. Thus, low ratings for this determinant attributes were expected. Only one attribute - potentials for holding congresses, conferences and exhibitions was given higher rating compared to Vojvodina Province competitors. This may be expected as Novi Sad, administrative centre of Vojvodina Province, has long tradition (almost one century) in organizing fairs, of which some are UFI (Union of International Fairs) approved events. Other destination attribute are not competitive. Destination recognition on European business tourism market and in the region, congress and visitor bureau services, clusters and other forms of cooperation in business tourism, as well as the investments in business tourism development are all rated relatively low compared to Vojvodina Province competitors. Also, tourism investments environment and membership in international associations, which is of great importance in bidding process, when members of an international association act as 
destination "ambassadors", trying to make one destination as attractive as possible for holding congress, are rated low compared to Vojvodina Province competitors. Business tourism is defined in Serbian and Vojvodina Province strategic tourism related documents as one of quick win tourist products. Therefore, low ratings for the above mentioned destination attributes should alarm all stakeholders interested in business tourism development in Vojvodina Province and should stimulate them to work together in order to provide better performance of Vojvodina Province at least on South-East European business tourism market.

\section{MEAN VALUES (M) AND STANDARD DEVIATIONS ( $\Sigma$ ) FOR INDIVIDUAL ATTRIBUTES OF DESTINATION POLICY, PLANNING AND DEVELOPMENT DETERMINANT}

\section{FIGURE 5}

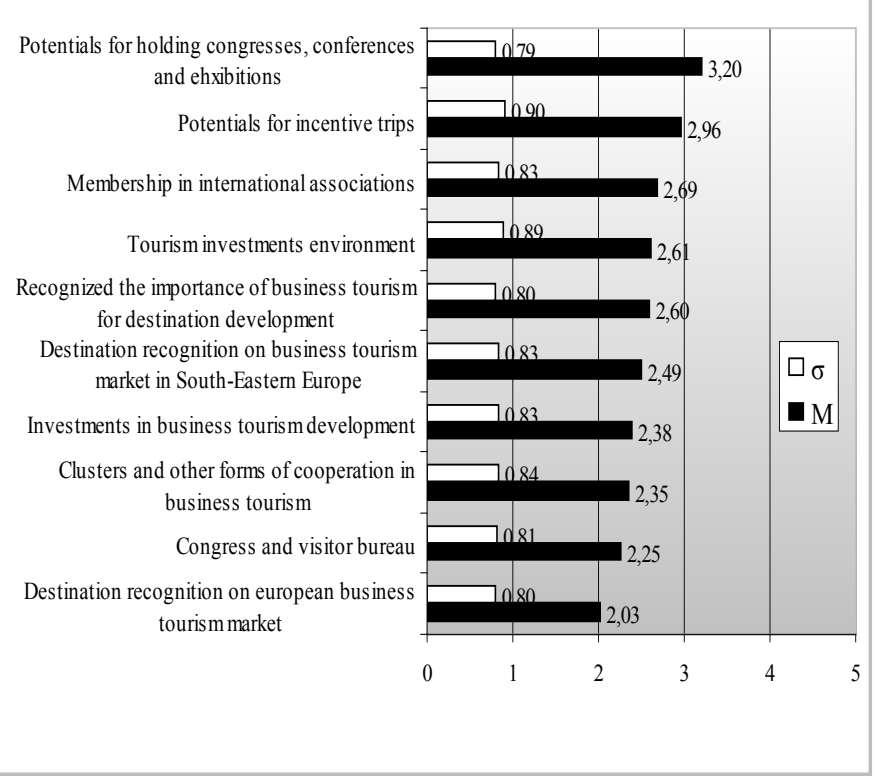

SOURCE: Author

In order to determine the weakest point of Vojvodina Province business tourism, mean values and standard deviations were calculated for each of the competitiveness determinants (Fig. 6). The highest rating was assigned to the core resources and attractors determinant, as expected. However, mean value of this determinant shows that destination attractiveness is not enough to provide competitive position of Vojvodina Province business tourism in the region. Other competitiveness determinants values were quite low. As it was expected, the weakest point in Vojvodina Province business tourism competitiveness is destination management, followed by destination policy, planning and development. The low standard deviations for all competitiveness determinants indicate a high level of agreement in respondents' opinions. Overall, the conclusion can be drawn that Vojvodina Province is not competitive business tourism destination compared to chosen set of competitive destinations. However, as Gomezelj and Mihaljič (2008, p. 294) state, "competitiveness can be improved through 
appropriate matches between tourism resources and management strategies supported by tourism stakeholders".

\section{MEAN VALUES (M) AND STANDARD DEVIATIONS ( $\Sigma$ ) FOR COMPETITIVENESS DETERMINANTS}

\section{FIGURE 6}

SOURCE: Author

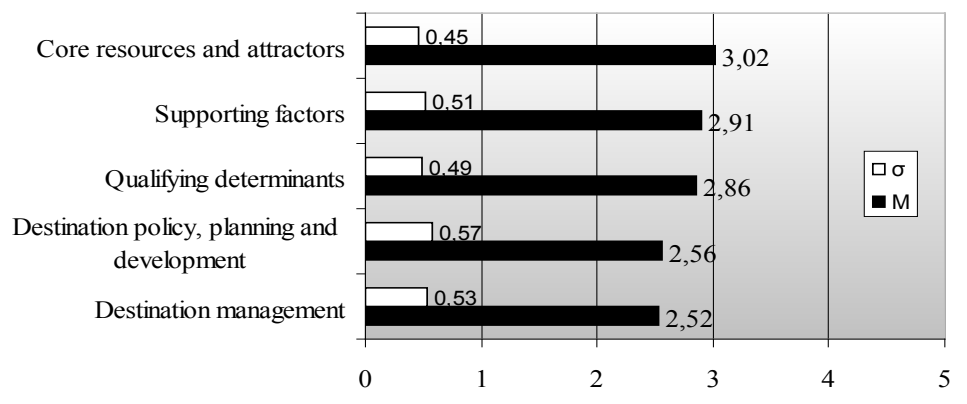

\section{Results of t-tests (Paired Samples)}

In order to study the competitiveness of destination management determinant, different hypotheses were created and Paired-Samples T test was used to test them.

The main hypothesis claims that destination management is the weakest determinant in Vojvodina Province business tourism competitiveness. In order to test it, four sub-hypotheses were created. The first sub-hypothesis assumes that Vojvodina Province business tourism is less competitive in management than in destination policy, planning and development. The second sub-hypothesis refers to management and qualifying and amplifying determinants and claims that management is again the weakest point of Vojvodina Province business tourism competitiveness. The third sub-hypothesis claims that Vojvodina Province is less competitive in destination management than in supporting factors, and the last sub-hypothesis refers to destination management and core resources and attractors. 
TABLE 1. Results of Paired-Samples T test (testing of competitiveness hypotheses)

Paired Differences

\begin{tabular}{|c|c|c|c|c|c|c|c|}
\hline & \multirow[t]{2}{*}{ Paired Variables } & \multirow[t]{2}{*}{ Mean } & \multirow[t]{2}{*}{$\begin{array}{c}\text { Std. } \\
\text { Deviation }\end{array}$} & \multicolumn{2}{|c|}{$\begin{array}{l}\text { 99\% Confidence } \\
\text { Interval of } \\
\text { the Difference }\end{array}$} & \multirow[t]{2}{*}{$\mathrm{t}$} & \multirow[t]{2}{*}{$\begin{array}{l}\text { Sig. } \\
\text { (2-tai- } \\
\text { led) }\end{array}$} \\
\hline & & & & Lower & Upper & & \\
\hline Pair 1 & $\begin{array}{l}\text { Destination management } \\
\text { - Destination policy }\end{array}$ & -0.03192 & 0.32917 & -0.11127 & 0.04743 & -1.053 & 0.294 \\
\hline Pair 2 & $\begin{array}{l}\text { Destination management } \\
\text { - Qualifying determinants }\end{array}$ & -0.33446 & 0.42340 & -0.43653 & -0.23240 & -8.581 & 0.000 \\
\hline Pair 3 & $\begin{array}{l}\text { Destination management } \\
\text { - Supporting factors }\end{array}$ & -0.38277 & 0.38887 & -0.47651 & -0.28903 & -10.692 & 0.000 \\
\hline Pair 4 & $\begin{array}{l}\text { Destination management } \\
\text { - Core resources }\end{array}$ & -0.49517 & 0.41335 & -0.59481 & -0.39553 & -13.013 & 0.000 \\
\hline
\end{tabular}

SOURCE: Author

The results in Table 1 indicate no statistically significant differences between destination management determinant and destination policy, planning and development determinant $(\mathrm{p}=0.294 ; \mathrm{t}=-1.053)$. Therefore, the first sub-hypothesis was rejected at 0.01 level. The lowest mean values were assigned to the above mentioned determinants (for destination management determinant $\mathrm{M}=2.52$, and for destination policy, planning and development determinant $\mathrm{M}=2.56$ ) with high level of agreement among respondents. Therefore, the conclusion can be drawn that these two determinants represent the weakest points of business tourism in Vojvodina Province. These results are in line with those presented in the Marketing strategy of Vojvodina Province tourism development (2009), as well as with the Serbian Strategy of tourism development (2005-2015).

Regarding the second sub-hypothesis, the results in Table 1 show that there is a statistically significant difference between destination management and qualifying determinants at 0.01 level $(\mathrm{p}=0.000 ; \mathrm{t}=-8.581)$. In other words, qualifying determinants more strongly support Vojvodina Province business tourism competitiveness than destination management. Also, Vojvodina Province is more competitive in supporting factors determinant and less in destination management and this was statistically proven $(\mathrm{p}=0.000 ; \mathrm{t}=-10.692)$. As expected, core resources turned out to be a stronger competitiveness determinant in the pair with destination management. Overall, it can be concluded that destination management determinant is the weakest point of Vojvodina Province business tourism, together with destination policy, planning and development determinant. These findings are in line with national and provincial strategic tourism related documents, which emphasis the problems linked to destination management and tourism policy. 


\section{CONCLUSIONS}

This study assessed the model of business tourism destination competitiveness and has advanced Crouch and Ritchie's 2003 Model of Destination Competitiveness in (business) tourism-specific competitiveness research. The created model was used to evaluate the competitiveness of Vojvodina Province business tourism. The results showed that Vojvodina Province is not competitive business tourism destination compared to chosen set of competitive destinations. Among five competitiveness determinants, tourism practitioners assigned the highest rating to core resources and attractors determinant ("at the same level in competitive destinations"), while other determinants were rated below the same level in competitive destinations. However, the results of individual attributes by determinants showed that Vojvodina Province is, compared to its competitors, more competitive in some of its core resources and attractors (multicultural ambience, gastronomy offer, entertainment, festival and events and cultural heritage attractiveness), as well as in some of supporting factors (hospitality of local residents) and qualifying and amplifying determinants (location, transport and hotel services costs and safety). These attributes make one destination more attractive for visiting or holding a business event and therefore, they should be in focus of Vojvodina Province marketing activities. The results of t-tests (paired samples) showed that two determinants: destination management and destination policy, planning and development, are the weakest points of Vojvodina Province business tourism competitiveness. It was statistically proven $(\mathrm{p}<0.01)$ that qualifying and amplifying determinants, supporting factors and core resources and attractors more strongly support Vojvodina Province business tourism competitiveness than destination management. Thus, it can be concluded that Vojvodina Province might become competitive business tourism destination in the region. It will require many improvements, specifically in the filed of promotion, destination image, tourism related and business tourism specialized human resources, investment environment and business tourism product planning and development.

Although this study provide a basis for overcoming identified disadvantages in Vojvodina Province tourism and specifically business tourism, it is limited by several factors that should be addressed in future research. More than $60 \%$ of the sample is represented by tourism academics and postgraduate students, while the rest of the sample consists of tourism stakeholders, congress bureau and other destination management organizations. Future researchers may focus their efforts on obtaining a larger number of respondents - tourism stakeholders, not academics. Also, to gain a better overview of Vojvodina Province business tourism competitiveness, future studies may expand the sample to include business events planners and professional organizers, as well as business events participants. Research might further compare views of business tourism supply and demand side on Vojvodina Province business tourism competitiveness. Also, the model of business tourism destination competitiveness created in this study, might be tested in other business tourism destinations, specifically in destinations identified as Vojvodina Province's primary competitors (Hungary, Slovenia and Croatia) and further comparison among destination competitiveness results could be done in order to get more general conclusions. Despite these limitations, the results of this study offer useful findings and pose some valuable managerial implications and directions for further research. 


\section{ACKNOWLEDGMENT}

This paper is part of the project No. 114-451-1861/2011-02 financed by the Provincial Secretariat for Science and Technological Development of the Vojvodina Province, Serbia.

\section{REFERENCES}

Baloglu, Şeyhmus, and Love, Curtis. 2001. Association meeting planners' perceptions of five major convention cities: Results of the pre-test. Journal of Convention \& Exhibition Management 3 (1): 21-30.

Bonn, Mark A., Joseph Sacha M. and Dai, Mo. 2005. International versus domestic visitors: An examination of destination image perceptions. Journal of Travel Research 43 (February): 294-301.

Buhalis, Dimitrios. 2000. Marketing the competitive destination of the future. Tourism Management 21 (January): 97-116.

Chacko, Harsha, and Fenich, George. 2000. Determining the importance of US convention destination attributes. Journal of Vacation Marketing 6 (July): 211-220.

Ching-Yaw, Chen, Sok Phyra, and Sok Keomony. 2008. Evaluating the Competitiveness of the Tourism Industry in Cambodia: Self-Assessment from Professionals. Asia Pacific Journal of Tourism Research 13 (March): 41-66.

Ching-Fu, Chen. 2006. Applying the Analytical Hierarchy Process (AHP) Approach to Convention Site Selection. Journal of Travel Research 45 (November): 167-174.

Cracolici, Maria Francesca, and Nijkamp, Peter. 2008. The attractiveness and competitiveness of tourist destinations: A study of Southern Italian regions. Tourism Management 30 (September): 336-344.

Croes, Robertico. 2005. Value as a Measure of Tourism Performance in the Era of Globalization: Conceptual Considerations and Empirical Findings. Tourism Analysis 9 (4): 255-67.

Crouch, Geoffrey, I., and Brent, Ritchie, J. R. 1999. Tourism, Competitiveness, and Societal Prosperity. Journal of Business Research 44 (3): 137-52.

Crouch, Geoffrey, I., and Louviere, Jordan J. 2004. The Determinants of Convention Site Selection: A Logistic Choice Model from Experimental Data. Journal of Travel Research 43 (November): 118-130.

Crouch, Geoffrey, I., and Brent, Ritchie, J. R. 2000. The competitive destination: A sustainability perspective. Tourism Management 21 (January): 1-7.

Crouch, Geoffrey, I., and Brent, Ritchie, J. R. 1998. Convention site selection research: A review conceptual model, and propositional framework. Journal of Conventions \& Exhibition Management 1 (1): 49-69.

Crouch, Geoffrey, I., and Weber, Karin. 2002. Marketing of convention tourism. In Convention tourism international research and industry perspectives, edited by Karin Weber and Kaye Chon. New York: Haworth Press Inc.

Crouch, Geoffrey, I. 2010. Destination Competitiveness: An Analysis of Determinant Attributes. Journal of Travel Research Online First XX (March): 1-19.

Davidson, Rob, and Cope, Beluah. 2003. Business Travel - Conferences, Incentive Travel, Exhibitions, Corporate Hospitality and Corporate Travel. London: Pearson Education.

Davidson, Rob. 1994. Business Travel. Addison Wesley Longman. 
De Holan, Pablo Martin, and Phillips, Nelson. 1997. Sun, Sand, and Hard Currency Tourism in Cuba. Annals of Tourism Research 24 (October): 777-795.

De Keyser, Robert, and Vanhove, N. 1994. The competitive situation of tourism in the Caribbean area - Methodological approach. Revue de Tourisme 3: 19-22.

DiPietro, Robin, B., Breiter, Deborah, Rompf, Paul and Godlewska, Marta. 2008. An Exploratory Study of Differences among Meeting and Exhibition Planners in their Destination Selection Criteria. Journal of Convention \& Event Tourism 9 (December): 258-276.

Dragićević, Vanja, Armenski, Tanja and Jovičić, Dobrica. 2009. Analyses of the Competitiveness of Novi Sad (Serbia) as a Regional Congress Destination. Tourism and Hospitality Management 15 (2): 247-256.

Dwyer, Larry and Kim, Chulwon. 2003. Destination competitiveness: Determinants and Indicators. Current Issues in Tourism 6 (5): 369-413.

Dwyer, Larry, Forsyth Peter and Rao Prasada. 2000. The price competitiveness of travel and tourism: A comparison of 19 destinations. Tourism Management 21 (February): 9-22.

Dwyer, Larry, Forsyth Peter and Rao Prasada. 2002. Destination price competitiveness: Exchange rate changes versus domestic inflation. Journal of Travel Research 40 (February): 328-336.

Dwyer, Larry, Livaic Zelko and Mellor, Robert. 2003. Competitiveness of Australia as a tourist destination. Journal of Hospitality and Tourism Management 10 (1): 60-78.

Enright, Michael, J. and Newton, James. 2004. Tourism destination competitiveness: A quantitative approach. Tourism Management 25 (December): 777-788.

Enright, Michael, J. and Newton, James. 2005. Determinants of tourism destination competitiveness in Asia Pacific: Comprehensiveness and universality. Journal of Travel Research 43 (May): 339-350.

Evans, Michael, R., Jerry B. Fox, and Roy B. Johnson, 1995. Identifying competitive strategies for successful tourism destination development. Journal of Hospitality and Leisure Marketing 31(1): 37-45.

Faulkner, Bill, Martin Opperman and Elizabeth Fredline. 1999. Destination competitiveness: An exploratory examination of South Australia's core attractions. Journal of Vacation Marketing 5 (2): 139-152.

Formica, Sandro. 2002. Measuring destination attractiveness: A proposed framework. Journal of American Academy of Business 1 (March): 350-355.

Gomezelj, Doris Omerzel, and Mihalič, Tanja. 2008. Destination competitivenessApplying different models, the case of Slovenia. Tourism Management 29 (Aprile): 294-307.

Gooroochurn, Nishaal, and Sugiyarto, Guntur. 2005. Competitiveness Indicators in the Travel and Tourism Industry. Tourism Economics 11 (March): 25-43.

Hassan, Salah S. 2000. Determinants of market competitiveness in an environmentally sustainable tourism industry. Journal of Travel Research 38 (February): 239-245.

Hong, Wei-Chiang. 2008. Competitiveness in the Tourism Sector, A Comprehensive Approach from Economic and Management Points Series. Contributions to Economics. Physica-Verlag Heidelberg.

Kim, Chulwon, and Dwyer, Larry. 2003. Destination competitiveness and bilateral tourism flows between Australia and Korea. Journal of Tourism Studies 14 (December): 55-67.

Kim, Hyun Jeong, Ming-Hsiang Chen and SooCheong Shawn Jang. 2006. Tourism Expansion and Economic Development: The Case of Taiwan. Tourism Management 27 (October): 925-33. 
Kim, Woo Gon, and Kim, Hyeon-Cheol, 2003. The Analysis of Seoul as an International Convention Destination. Journal of Convention and Exhibition Management 5 (2): 69-87.

Kozak, Metin, and Rimmington, Mike. 1999. Measuring Tourist Destination Competitiveness: Conceptual Considerations and Empirical Findings. International Journal of Hospitality Management 18 (3): 273-83.

Mangion, Marie-Louise, Ramesh Durbarry and Sinclair M. Thea. 2005. Tourism Competitiveness: Price and Quality. Tourism Economics 11(March): 45-68.

Marketing Strategy of Vojvodina Province Tourism Development. 2009. Novi Sad.

Mazanec, Josef A., Karl Wober and Zins Andreas H. 2007. Tourism Destination Competitiveness: From Definition to Explanation. Journal of Travel Research 46 (August): 86-95.

Mihalič, Tanja. 2000. Environmental management of a tourist destination A factor of tourism competitiveness. Tourism Management 21 (February): 65-78.

Miller, Mark, M., Tony, L. Henthorne and George, Babu, P. 2008. The Competitiveness of the Cuban Tourism Industry in the Twenty-First Century:A Strategic Re-Evaluation. Journal of Travel Research 46 (February): 268-278.

Oppermann, Martin. 1996. Convention destination images: analysis of association meeting planners' perceptions. Tourism Management 17 (May): 175-182.

Oppermann, Martin, and Chon, Kye-Sung. 1997. Convention Participation Decisionmaking Process. Annals of Tourism Research 24 (1): 178-191.

Papatheodorou, Andreas, and Song, Hayian. 2005. International Tourism Forecasts: Time-Series Analysis of World and Regional Data. Tourism Economics 11 (March):11-23.

Porter, Michael E. 1990. The Competitive Advantage of Nations. New York: Free Press.

Qu, Hailin, Li Lan, and Chu Gilder Kei Tat. 2000. The comparative analysis of Hong Kong as an international conference destination in Southeast Asia. Tourism Management 21 (December): 643-648.

Ritchie, Brent J. R. and Crouch, Geoffrey I. 1993. Competitiveness in international tourism-a framework for understanding and analysis. Reports on 43rd Congress, 35: 23-71.

Ritchie, Brent J. R. and Crouch, Geoffrey I. 2003. The Competitive Destination, A Sustainable Tourism Perspective. Wallingford, Oxon: CABI Publishing.

Sahli, Mondher. 2006. Tourism Destination Specialization. In International Handbook on the Economics of Tourism edited by Larry Dwyer and Peter Forsyth. Northampton: Edward Elgar Publishing.

Scott, Bruce R. and Lodge, George C. 1985. US Competitiveness in the World Economy. Boston, Massachusetts: Harvard Business School Press.

Sirše, Janez, and Mihalič, Tanja. 1999. Slovenian tourism and tourism policy - a case study. Revue de Tourisme 54 (3): 34-47.

Strategy of Tourism Development of the Republic of Serbia 2005-2015. Belgrade.

Swarbrooke, John, and Horner, Susan. 2001. Business Travel and Tourism. Oxford: Butterworth-Heinemann.

The Organization for Economic Cooperation \& Development (OECD). 1994. The World Competitiveness Report. Lausanne: World Economic Forum and IMD International.

WTO. 2007. A Practical Guide to Tourism Destination Management. Madrid: World Tourism Organization.

Yoo, Joanne Jung-Eun and Chon, Kaye. 2008. Factors Affecting Convention Participation Decision-Making: Developing a Measurement Scale. Journal of Travel Research 47 (August): 
Economic Research - Ekonomska istraživanja, Vol. 25 (2012) No. 2 (311-332)

113-122.

Zhang, Hanqin Qiu, Vivien Leung and Hailin Qu. 2007. A refined model of factors affecting convention participation decision-making. Tourism Management 28 (August): $1123-1127$. 


\title{
POSLOVNA KONKURENTNOST TURISTIČKE DESTINACIJE: SLUČAJ REGIJE VOJVODINE (SRBIJA)
}

\author{
SAŽETAK
}

Svrha ovog rada je kreirati model za mjerenje konkurentnosti destinacije poslovnog turizma i testirati ga na primjeru Vojvodine, turističkog klastera u Srbiji, gdje je poslovni turizam definiran kao jedan od ključnih turističkih proizvoda. Cilj rada je ispitati u kojim područjima je poslovni turizam Vojvodine više, odnosno manje, konkurentan u usporedbi s "konkurentnim setom" koji čine tri odabrane destinacije. Takoder, cilj rada je testirati veze izmedu determinanti modela konkurentnosti destinacije da bi se odredile najslabije točke poslovnog turizma Vojvodine, a naročito da bi se ustanovila pozicija determinante menadžment destinacije. Rezultati istraživanja pokazuju da su dvije determinante: menadžment destinacije i destinacijska politika, planiranje i razvoj, najslabije determinante konkurentnosti Vojvodine, dok su najveće ocijene dodijeljene determinanti ključni resursi i atrakcije. Rezultati će biti od koristi destinacijskim menadžment organizacijama, kreatorima turističke politike i turističkoj privredi da bolje razumiju identificirane nedostatke i probleme u poslovnom turizmu i općenito turizmu Vojvodine i da formuliraju strategije kojima će se efikasno upravljati destinacijom.

Ključne riječi: konkurentnost destinacije, poslovni turizam, Vojvodina. 
Economic Research - Ekonomska istraživanja, Vol. 25 (2012) No. 2 (311-332) 